\title{
Living in the Presence of Death: An Integrative Literature Review of Relatives' Important Existential Concerns when Caring for a Severely III Family Member
}

\author{
Christina Melin-Johansson ${ }^{*}$, Ingela Henoch ${ }^{2,3,6}$, Susann Strang ${ }^{4,6}$ and Maria Browall ${ }^{5,6,7}$ \\ ${ }^{I}$ Mid Sweden University, Department of Health Sciences, Östersund, Sweden \\ ${ }^{2}$ Bräcke Diakoni Foundation, Research Unit, Gothenburg, Sweden \\ ${ }^{3}$ Karolinska Institutet, Institution of Learning, Informatics, Management and Ethics, Medical Management Centre, \\ Stockholm, Sweden \\ ${ }^{4}$ Angered Local Hospital, Gothenburg, Sweden \\ ${ }^{5}$ Sahlgrenska University Hospital, Department of Oncology, Clinical Trial Unit. Gothenburg, Sweden \\ ${ }^{6}$ The Sahlgrenska Academy, University of Gothenburg, Institute of Health and Care Sciences, Sweden \\ ${ }^{7}$ School of Life Sciences, University of Skövde, Sweden
}

\begin{abstract}
Aim: The aim of this study was to explore relatives' existential concerns when caring for a seriously ill family member as well as to describe interventions that meet these concerns.

Methods: In this integrative literature review we assessed and classified 17 papers, 12 qualitative and 5 quantitative. Literature was sought in the databases Cinahl, PubMed, Psykinfo and Web of Science in September 2009 and in March 2010. Search terms used in different combinations were: family, family caregiver, next of kin, relatives, palliative, palliative care, end-of-life care, existential, spirit*. Data were redrawn from the papers results/findings, and synthesized into a new descriptive content.

Results: The results were categorized from 13 papers exploring relatives' important existential concerns and 4 papers describing interventions aimed to support them in the existential area. A majority of the reviewed papers had been written in Sweden and concerned relatives of patients with cancer. One overarching theme, living in the presence of death, and three categories: responses to life close to death; support when death is near; and beyond the presence of death were created.

Conclusion: There is an urgent demand for large-scale studies using accurate methodology, as well as a need to design qualified investigations regarding the effects of various interventions, and to determine which interventions are the most effective in supporting relatives who experience existential distress manifested physically and/or psychologically. There is also a considerable demand for educational interventions among professionals in various healthcare settings to increase their knowledge regarding existential concerns among relatives.
\end{abstract}

Keywords: Cancer, end-of-life care, family, incurable illness, nursing, review.

\section{INTRODUCTION}

In palliative care, relatives are often the primary care giver for persons with a serious illness. Their situation is difficult as they struggle with daily life while at the same time wanting to provide the best possible care. Relatives' burdens increase as the seriously ill person proceeds from being quite active to becoming more and more bedridden. Care moves to other levels and new goals must be identified which may lead to feelings of aggravation and even burnout [1]. The future is unpredictable and relatives have to make difficult decisions', often by themselves. Some relatives try to become as prepared as possible in this complex situation

*Address correspondence to this author at the Mid Sweden University, Department of Health Sciences, Östersund, Sweden; Tel: +43 63 165672; Fax:+43 63 165626; E-mail: titti.melin-johansson@miun.se by searching for meaning, taking farewell and reaching religious and spiritual closure [2]. In this situation many relatives need support, but little is known about existing supportive interventions.

The importance of the patients' existential concerns in end of life care was described by Cicely Saunders in the 1960:s when she introduced the term total pain, including the physical, psychological, social, and spiritual dimension [3], and became a part of the World Health Organizations' definition of palliative care [4]. Existential needs are significant for patients with cancer, which is rather well described in literature [5]. Existential needs are described in other studies as people's intense desire to infuse life and maintain a meaning in life [6-8], with freedom and relations [6], as well as sustaining purpose and hope [7, 8], and a desire to obtain feelings of peace [9]. The existential threats 
concern the loss of functions [10], control, social role functioning, continuity, relations, independency and the future $[11,12]$. Saunders [3] emphasizes that meaninglessness is the essence of existential distress, and often concerns different losses. Other sources of distress are a changed personality and anxiety for death [10], dependency and feeling emotionally unrelated [13], or uncompleted life tasks and acceptance/preparation [11]. Living with cancer involves issues of transcendence, and spiritual well-being is improved by a person's religion, sense of hopefulness, having a purpose in life, and other sources of spiritual support [7].

Relatives experience their situation as stressful and feelings of vulnerability are created when caring for a seriously ill family member. They want to be close to the ill person knowing that time is limited. It is also difficult being more aware about the situation than the ill family member, as is talking about death and dying in such a situation. Relatives often feel uninformed about the patient's situation and lack guidance and support from healthcare professionals. Their needs differ from the patients as they are concerned that the care is not good enough for the patient while they are constantly by the patients' side, struggling to prepare a situation that can differ from day to day [14]. Relatives also experience that they are quite unprepared for the suddenness of their role and the level of responsibility entailed in caring for a seriously ill family member. Furthermore, they felt inadequately prepared for the unpredictable nature of care giving and the timing of death [15]. Relatives' role as the

\section{Searches September 2009 and March 2010}

Search terms: family, family caregiver, next of kin, relatives, palliative, palliative care, end of life care, existential, spirit*, spirituality, spiritual. The search terms was used in different combinations. A total of 74 papers where included, read and assessed at this stage.

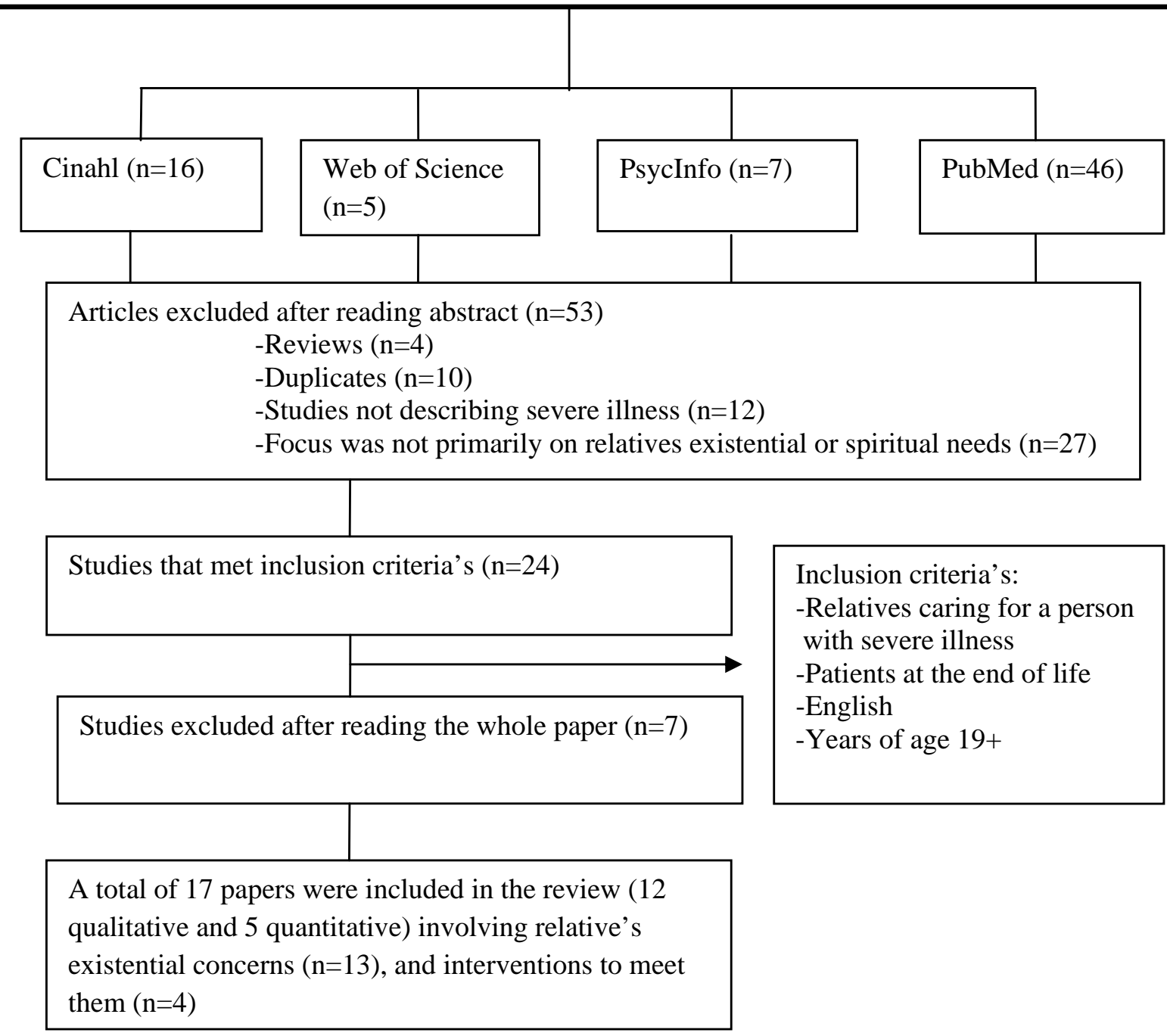

Fig. (1). Overview of sampling procedure. 
primary caregiver in caring for a seriously ill family member, who is facing death, may alert the relative's own existential needs. They are in a vulnerable position and more information is required concerning what existential needs are actualized while facing the death of a close family member. Furthermore knowledge regarding the kind of interventions likely to be effective in meeting these complex needs is not earlier reviewed in the literature.

\section{AIM}

The aim of this study was to explore relatives' existential concerns when caring for a seriously ill family member as well as to describe interventions that meet these concerns.

\section{METHOD}

In this integrative literature review 17 empirical studies were analyzed qualitatively. We assessed primary sources that described what alerts relatives' existential emotions when caring for a person at the end of life, and the kind of support the relatives require in this vulnerable situation.

Literature was sought and found in the databases Cinahl, Pub Med, PsycInfo and Web of Science. No suitable paper was found in the Cochrane database. The search was restricted to adults, not child and peer reviewed and the language was English or Swedish (Fig. 1). When samples in the paper included patients, relatives or healthcare professionals text was extracted that described existential issues from the relative's perspective. The initial search was performed in September 2009 and a complementary search was conducted in March 2010.

All authors were involved in the stages of the review process concerning:

1) identifying the research questions and,

2) searching literature. The literature was divided between the authors with the aim to evade that one of the authors reviewed papers written by herself.

3) Papers that met inclusion criteria's were read by all authors, and

4) classified using a tool published by SBU [16]. Quantitative studies are divided in randomized controlled studies (RCT), clinical trials (CCT) and descriptive studies (DS) according to Goodman [17]. The studies were assessed according to sample size, well defined objectives, adequate described statistical methods and longitudinal studies. A qualitative study is when data are collected with interviews, narratives, or observations with the aim to get a deeper understanding of a person's life world $[16,18]$. The qualitative studies were assessed due to trustworthiness as well described research process, interpretations and conclusions. A scale was used when assessing the quality in included quantitative and qualitative studies, high (grade I) or low quality (grade III), a medium grade (II) were used if a study did not meet the criteria's for grade I or III.

5) The review process continued systematically by reapplying data from results/findings compiled in a spreadsheet,
6) coding data and sorted item per item; similar data were grouped together,

7) categorizing the content comparing them with each other concerning similarities and differences,

8) and synthesizing data into a new descriptive content.

A total of 17 papers were included in this integrative literature review of which 12 were qualitative and 5 quantitative. An overview of the papers presented in the result is described in Table $\mathbf{1}$.

\section{RESULTS}

The results from our literature review is divided into 13 qualitative studies exploring important existential concerns for relatives and 4 quantitative studies describing interventions aimed to support and guide relatives existentially. We did not find any interventions with randomized, controlled design. A total of 877 relatives, mainly spouses of patients with cancer were included in these studies. Seven studies included both patients and relatives, and one study included patients, relatives and nurses. An overview of the patients and relatives participating in the different papers are presented in Table $\mathbf{1}$. Ten papers were from Sweden, the rest were from USA (3), Canada (1), Israel (1), Taiwan (1) and Greece (1). When analyzing important existential concerns in the papers, one overarching theme, Living in the presence of death, 3 categories and 9 subcategories were created (Table 2).

\section{RESPONSES TO LIFE CLOSE TO DEATH}

\section{Social Decline}

Relatives were often reminded of death e.g. due to the hospital environment [19], and the fact that they were about to lose their everyday life - i.e. normalcy was threatened [20]. Relatives of patients with brain tumors experienced that their partner just seemed to slip away; they lost their social life due to the patient's changing personality [19]. This was a kind of social death. Relatives of patients with other malignancies no longer shared the same plans for the future or long-term life plans with their partners as they had done previously [21]. Thoughts of a common future with careers, grandchildren or retirement had to be abandoned, because they would not meet the future together. Some of the external fellowship they had shared with others ceased to exist, since the ill person no longer had the strength to socialize with friends outside the close family. The patient's impaired function in daily life also restricted the ability to live a normal life, subsequently reducing autonomy and increasing loneliness [22]. Another study showed that spouses have significant lower levels of social support from friends and family compared with patients [23].

\section{Physical Expressions}

The patient's physical suffering reminded relatives of death and they were worried about the patient's poor symptom control and struggle to survive [22]. The relatives were always aware of the patient's suffering, deteriorating health and declining strength. The relatives felt powerless in the face of the patient's suffering, with physical symptoms, as pain, fatigue and breathlessness $[21,22]$. The fact that the 
Table 1. Overview of the Literature and Relation to Categories

\begin{tabular}{|c|c|c|c|c|c|}
\hline $\begin{array}{l}\text { Authors and } \\
\text { Country }\end{array}$ & $\begin{array}{l}\text { Aim or Motivation for } \\
\text { the Study }\end{array}$ & Design and Sample & Main Findings & Category & $\begin{array}{c}\text { Grade of Classification } \\
\text { K=Qualitative Studies } \\
\text { (n=12) } \\
\text { DS=Descriptive Studies } \\
\text { (Quantitative } \mathbf{n}=\mathbf{5}) \\
\text { Grade I= High } \\
\text { Grade II= Medium } \\
\text { Grade III= Low Quality }\end{array}$ \\
\hline $\begin{array}{c}\text { Adelbratt, Strang } \\
(2000) \\
\text { Sweden }\end{array}$ & $\begin{array}{l}\text { To explore to what extent } \\
\text { patients and their next of } \\
\text { kin experience death } \\
\text { anxiety, and how these } \\
\text { experiences are expressed }\end{array}$ & $\begin{array}{c}\text { Qualitative } \\
20 \text { patients with brain } \\
\text { tumours and } 15 \text { next } \\
\text { of kin } \\
\text { Interviews were } \\
\text { analyzed with content } \\
\text { and context analysis }\end{array}$ & $\begin{array}{l}\text { Six categories emerged } \\
\text { concerning patients; (1) } \\
\text { emotional reactions that } \\
\text { could be related to death } \\
\text { anxiety (2) existential fear } \\
\text { (3) contradictions; (4) } \\
\text { trigger situations (5) coping } \\
\text { strategies (6) new values for } \\
\text { life. Besides these } \\
\text { categories, a further } \\
\text { category emerged; } \\
\text { experiences characteristic of } \\
\text { the next of kin. }\end{array}$ & $\begin{array}{l}\text { Response to } \\
\text { life close to } \\
\text { death }\end{array}$ & KI \\
\hline $\begin{array}{c}\text { Albinsson, Strang } \\
\text { (2003) } \\
\text { Sweden }\end{array}$ & $\begin{array}{c}\text { To focus on issues of } \\
\text { freedom/responsibility, } \\
\text { existential isolation, } \\
\text { death, and issues } \\
\text { of } \\
\text { meaning/meaninglessness. }\end{array}$ & $\begin{array}{c}\text { Qualitative } \\
20 \text { family members of } \\
\text { people with severe/ } \\
\text { late stage dementia. } \\
\text { In-depth interviews } \\
\text { were analyzed with a } \\
\text { hermeneutic } \\
\text { approach. }\end{array}$ & $\begin{array}{l}\text { To take responsibility was } \\
\text { generally perceived as } \\
\text { rewarding, but in some } \\
\text { cases it was more a matter } \\
\text { of duty with elements of } \\
\text { guilt and obligation. } \\
\text { Positive aspects of } \\
\text { responsibility and the future } \\
\text { involved passing on the } \\
\text { patient's lifework. }\end{array}$ & $\begin{array}{l}\text { Response to } \\
\text { life close to } \\
\text { death } \\
\text { Beyond the } \\
\text { presence of } \\
\text { death }\end{array}$ & K II \\
\hline $\begin{array}{c}\text { Arnaert, Gabos et } \\
\text { al. }(2010) \\
\text { Canada }\end{array}$ & $\begin{array}{l}\text { Relatives play a key role } \\
\text { in the daily support and } \\
\text { care of cancer patients. } \\
\text { This role, however, can } \\
\text { negatively affect relatives } \\
\text { physically, } \\
\text { psychologically, } \\
\text { emotionally, and } \\
\text { spiritually, challenging } \\
\text { their health and well- } \\
\text { being. Consequently, } \\
\text { this could inhibit } \\
\text { relatives' abilities to } \\
\text { continue in their roles as } \\
\text { caregivers. }\end{array}$ & $\begin{array}{c}\text { Qualitative } \\
\text { intervention study } \\
8 \text { relatives of people } \\
\text { diagnosed with } \\
\text { cancer stage III and } \\
\text { IV. } \\
\text { Semi structured } \\
\text { interviews to explore } \\
\text { the experiences of } \\
\text { attending a "Skills for } \\
\text { Healing Retreat } \\
\text { Weekend". } \\
\text { Analyzed with } \\
\text { content analysis using } \\
\text { the constant } \\
\text { comparative method }\end{array}$ & $\begin{array}{l}\text { Bringing people together to } \\
\text { partake in discussions and } \\
\text { activities fostered a sense of } \\
\text { community among the } \\
\text { participants. The retreat had } \\
\text { enduring effects, } \\
\text { contributing to relatives' } \\
\text { ongoing processes of } \\
\text { healing as well as providing } \\
\text { them with strategies for } \\
\text { coping in their roles as } \\
\text { caregivers. }\end{array}$ & $\begin{array}{l}\text { Support when } \\
\text { death is near }\end{array}$ & KII \\
\hline $\begin{array}{c}\text { Axelsson, Sjöden } \\
(1998) \\
\text { Sweden }\end{array}$ & $\begin{array}{l}\text { To gather knowledge } \\
\text { about the quality of life } \\
\text { both of terminally ill } \\
\text { cancer patients and their } \\
\text { spouses. }\end{array}$ & $\begin{array}{l}\text { Quantitative } \\
\text { Using Assessment of } \\
\text { Quality of life at the } \\
\text { End of Life (AQEL) } \\
37 \text { incurably ill } \\
\text { cancer patients and } \\
\text { their spouses, } \\
\text { receiving support } \\
\text { from a hospital-based } \\
\text { palliative service }\end{array}$ & $\begin{array}{l}\text { Spouses were more anxious } \\
\text { than patients. The least- } \\
\text { optimal items at the end of } \\
\text { life for spouses were: ability } \\
\text { to leave the patient } \\
\text { unattended, need for } \\
\text { assistance with } \\
\text { hygiene/dressing and } \\
\text { anxiety. Spouses found that } \\
\text { meaningfulness was the } \\
\text { item with the strongest } \\
\text { correlation to global quality } \\
\text { of life. }\end{array}$ & $\begin{array}{l}\text { Response to } \\
\text { life close to } \\
\text { death } \\
\text { Beyond the } \\
\text { presence of } \\
\text { death }\end{array}$ & DSII \\
\hline
\end{tabular}




\begin{tabular}{|c|c|c|c|c|c|}
\hline $\begin{array}{l}\text { Authors and } \\
\text { Country }\end{array}$ & $\begin{array}{l}\text { Aim or Motivation for } \\
\text { the Study }\end{array}$ & Design and Sample & Main Findings & Category & $\begin{array}{c}\text { Grade of Classification } \\
\text { K= Qualitative Studies } \\
\text { (n=12) } \\
\text { DS=Descriptive Studies } \\
\text { (Quantitative } n=5) \\
\text { Grade I= High } \\
\text { Grade II= Medium } \\
\text { Grade III= Low Quality }\end{array}$ \\
\hline $\begin{array}{c}\text { Benzein,Saveman } \\
\text { (2008) } \\
\text { Sweden }\end{array}$ & $\begin{array}{l}\text { To describe couples' } \\
\text { experiences of } \\
\text { participating in nurse- } \\
\text { initiated health-promoting } \\
\text { conversations about hope } \\
\text { and suffering during } \\
\text { home-based palliative } \\
\text { care. }\end{array}$ & $\begin{array}{l}\text { Qualitative } \\
\text { intervention study } \\
6 \text { couples (6 spouses } \\
\text { caring for a dying } \\
\text { relative with cancer) } \\
\text { participated in a } \\
\text { health promotion } \\
\text { conversation. } \\
\text { Semi-structured } \\
\text { interviews analyzed } \\
\text { with its content. }\end{array}$ & $\begin{array}{l}\text { Talking with nurses about } \\
\text { existential issues such as } \\
\text { hope and suffering made } \\
\text { couples feel that they were } \\
\text { part of a trustful } \\
\text { relationship, and that it was } \\
\text { a healing experience. }\end{array}$ & $\begin{array}{l}\text { Support when } \\
\text { death is near }\end{array}$ & K II \\
\hline $\begin{array}{c}\text { Cronfalk et al. } \\
\text { (2009) } \\
\text { Sweden }\end{array}$ & $\begin{array}{l}\text { To explore relatives' } \\
\text { experiences of receiving } \\
\text { soft tissue massage as a } \\
\text { support supplement while } \\
\text { caring for a dying family } \\
\text { member at home. }\end{array}$ & $\begin{array}{l}\text { Qualitative } \\
\text { intervention study } \\
19 \text { relatives of people } \\
\text { who were dying or } \\
\text { had severe illness. } \\
\text { Semi-structured } \\
\text { interviews analyzed } \\
\text { with content analysis }\end{array}$ & $\begin{array}{l}\text { Soft tissue massage gave a } \\
\text { feeling of being cared for, } \\
\text { energized the body and } \\
\text { peace of mind. The } \\
\text { overarching theme was } \\
\text { 'inner power, physical } \\
\text { strength and existential } \\
\text { well-being in their daily } \\
\text { lives'. }\end{array}$ & $\begin{array}{l}\text { Support when } \\
\text { death is near }\end{array}$ & K I \\
\hline $\begin{array}{l}\text { Hasson-Ohayon, } \\
\text { Goldzweig et al. } \\
\quad(2009) \\
\text { Israel }\end{array}$ & $\begin{array}{l}\text { The current study } \\
\text { examines the effect of } \\
\text { perceived support from } \\
\text { different agents } \\
\text { (spouse, family, friends, } \\
\text { religion - spirituality) on } \\
\text { psychological distress } \\
\text { experienced by women } \\
\text { with advanced breast } \\
\text { cancer and their male } \\
\text { spouses. }\end{array}$ & $\begin{array}{l}\text { Quantitative } \\
150 \text { couples (women } \\
\text { with advanced breast } \\
\text { cancer and their } \\
\text { spouses) completed } \\
\text { the Cancer Perceived } \\
\text { Agent of Support } \\
\text { Questionnaire and the } \\
\text { Brief Symptom } \\
\text { Inventory Scale } \\
\text { analyzed with } \\
\text { descriptive statistics. }\end{array}$ & $\begin{array}{l}\text { Spouses reported a lower } \\
\text { level of support provided } \\
\text { from family and friends. } \\
\text { Spouses were more } \\
\text { depressed and anxious than } \\
\text { patients. Perceived support } \\
\text { contributed significantly to } \\
\text { the explanations of global } \\
\text { psychological distress, } \\
\text { depression and anxiety. } \\
\text { Religious-based support } \\
\text { was found to contribute } \\
\text { negatively to the } \\
\text { psychological distress.. }\end{array}$ & $\begin{array}{l}\text { Response to } \\
\text { life close to } \\
\text { death } \\
\text { Support when } \\
\text { death is near }\end{array}$ & DSI \\
\hline $\begin{array}{l}\text { Hebert et al. } \\
(2008) \\
\text { USA }\end{array}$ & $\begin{array}{l}\text { To determine what } \\
\text { questions family } \\
\text { caregivers want to discuss } \\
\text { with health care providers } \\
\text { (HCPs) in order to } \\
\text { prepare for the death of a } \\
\text { loved one. }\end{array}$ & $\begin{array}{c}\text { Qualitative } \\
33 \text { current and } \\
\text { bereaved caregivers } \\
\text { of terminally ill } \\
\text { patients (cancer, } \\
\text { cardiovascular } \\
\text { disease, } \\
\text { COPD/pneumonia, } \\
\text { cirrhosis, dementia, } \\
\text { multiple illnesses). } \\
\text { Ethnographic } \\
\text { interviews and focus } \\
\text { groups analyzed } \\
\text { using standard } \\
\text { methods. }\end{array}$ & $\begin{array}{l}\text { Caregivers had a wide } \\
\text { spectrum of questions to } \\
\text { discuss with HPCs, and } \\
\text { were medical, practical, } \\
\text { psycho-social, or } \\
\text { religious/spiritual in nature. } \\
\text { Barriers to asking questions } \\
\text { were feeling overwhelmed, } \\
\text { "not knowing what to ask," } \\
\text { the perception that HCPs } \\
\text { were untrust-worthy, and } \\
\text { worries about being } \\
\text { perceived as "ignorant". }\end{array}$ & $\begin{array}{l}\text { Support when } \\
\text { death is near }\end{array}$ & KI \\
\hline
\end{tabular}




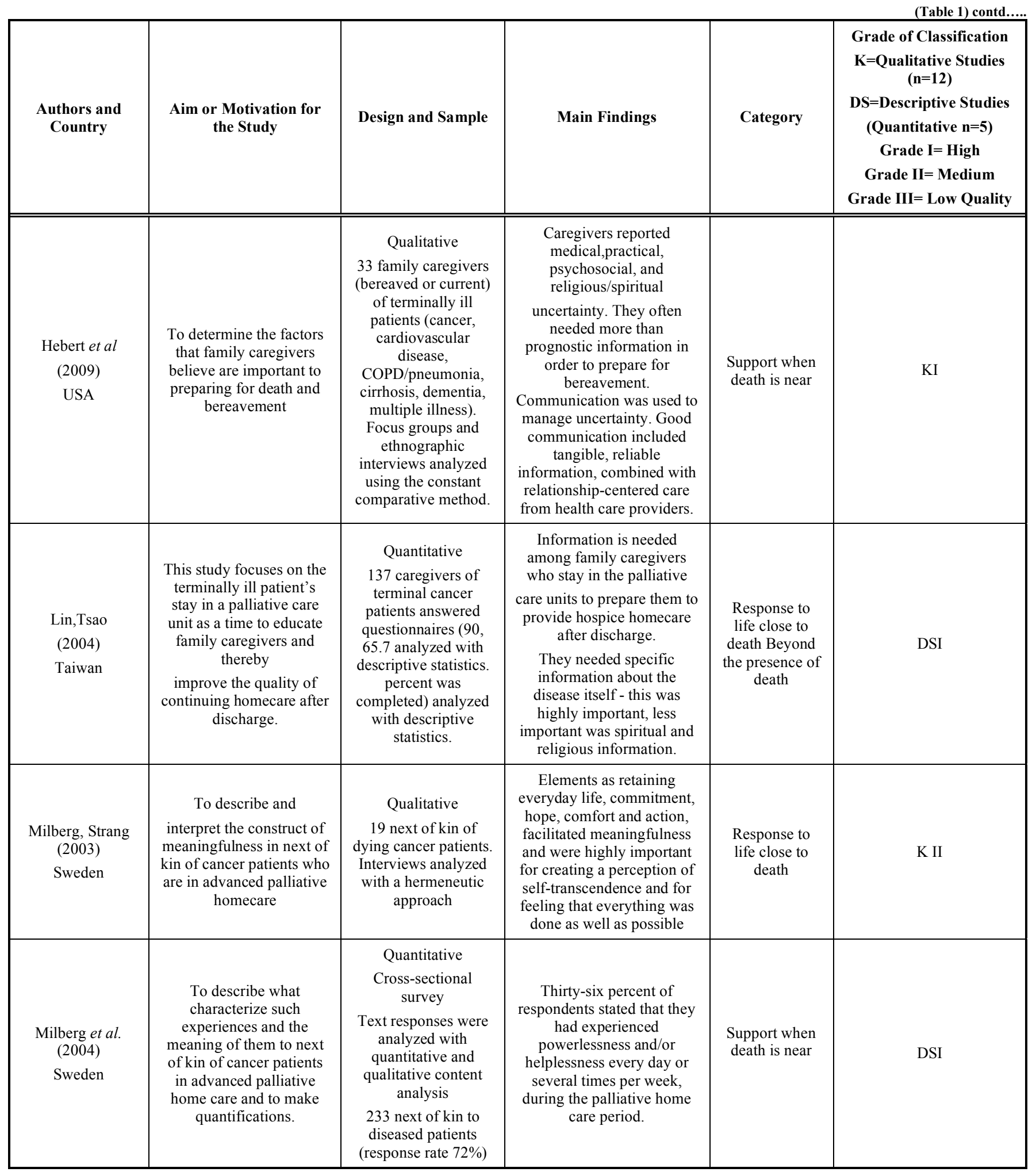




\begin{tabular}{|c|c|c|c|c|c|}
\hline $\begin{array}{l}\text { Authors and } \\
\text { Country }\end{array}$ & $\begin{array}{c}\text { Aim or Motivation for } \\
\text { the Study }\end{array}$ & Design and Sample & Main Findings & Category & $\begin{array}{c}\text { Grade of Classification } \\
\text { K=Qualitative Studies } \\
(\mathbf{n}=12) \\
\text { DS=Descriptive Studies } \\
\text { (Quantitative } \mathbf{n}=\mathbf{5}) \\
\text { Grade I= High } \\
\text { Grade II= Medium } \\
\text { Grade III= Low Quality }\end{array}$ \\
\hline $\begin{array}{c}\text { Rosenbaum et al. } \\
(2006) \\
\text { USA }\end{array}$ & $\begin{array}{l}\text { To illuminate how } \\
\text { existential factors may } \\
\text { underlie some of the } \\
\text { psychological benefits of } \\
\text { family support, we } \\
\text { explain one aspect of } \\
\text { existential coping - } \\
\text { symbolic immortality - } \\
\text { and describe ways in } \\
\text { which existential and } \\
\text { social support factors } \\
\text { work together during a } \\
\text { Life Tape (LT). }\end{array}$ & $\begin{array}{l}\text { Qualitative } \\
\text { intervention study } \\
35 \text { patients with } \\
\text { cancer and their } \\
\text { families } \\
\text { Videotaped } \\
\text { interviews }\end{array}$ & $\begin{array}{l}\text { Few interventions have been } \\
\text { developed to help families } \\
\text { support patients in dealing } \\
\text { with fears of death and } \\
\text { dying. The Life Tape } \\
\text { Project (LTP) brings } \\
\text { families closer together, } \\
\text { increases communication, } \\
\text { and acts as an existential } \\
\text { intervention. }\end{array}$ & $\begin{array}{l}\text { Response to } \\
\text { life close to } \\
\text { death }\end{array}$ & K III \\
\hline $\begin{array}{l}\text { Sand, Strang } \\
\quad(2006) \\
\text { Sweden }\end{array}$ & $\begin{array}{c}\text { To focus on the emotions, } \\
\text { perceptions, and } \\
\text { experiences of existential } \\
\text { isolation in palliative } \\
\text { patients } \\
\text { with cancer and their } \\
\text { families }\end{array}$ & $\begin{array}{c}\text { Qualitative } \\
20 \text { patients (early or } \\
\text { late palliative phase) } \\
\text { and } 20 \text { family } \\
\text { members } \\
\text { Semi-structured } \\
\text { interviews analyzed } \\
\text { with existential } \\
\text { hermeneutics }\end{array}$ & $\begin{array}{l}\text { The data revealed } \\
\text { experiences of existential } \\
\text { loneliness with impending } \\
\text { death as a primary source. } \\
\text { Changes in one's own body } \\
\text { and mood gave rise to } \\
\text { feelings of loneliness. }\end{array}$ & $\begin{array}{l}\text { Support when } \\
\text { death is near }\end{array}$ & K I \\
\hline $\begin{array}{c}\text { Strang, Strang et } \\
\text { al. }(2001) \\
\text { Sweden }\end{array}$ & $\begin{array}{l}\text { To describe the opinions } \\
\text { of nurses, patients and } \\
\text { next-of-kin on existential } \\
\text { support and how this is } \\
\text { prioritized. }\end{array}$ & $\begin{array}{c}\text { Qualitative } \\
20 \text { patients with brain } \\
\text { tumour (grade II-IV), } \\
16 \text { family members } \\
\text { and } 16 \text { nurses } \\
\text { Semi-structured } \\
\text { interviews analyzed } \\
\text { with } \\
\text { phenomenography }\end{array}$ & $\begin{array}{l}\text { Patients and family } \\
\text { members were satisfied with } \\
\text { the medical and physical } \\
\text { treatment, but not with the } \\
\text { existential support. }\end{array}$ & $\begin{array}{l}\text { Support when } \\
\text { death is near }\end{array}$ & K I \\
\hline $\begin{array}{l}\text { Syrén, Saveman } \\
\text { et al. } \\
(2006) \\
\text { Sweden }\end{array}$ & $\begin{array}{l}\text { To illuminate the way of } \\
\text { being a family when one } \\
\text { family member is in the } \\
\text { midst of living and dying }\end{array}$ & $\begin{array}{c}\text { Qualitative } \\
5 \text { families }(\mathrm{N}=48) \\
\text { each containing one } \\
\text { family member with } \\
\text { cancer. Narrative } \\
\text { interviews were } \\
\text { analyzed according to } \\
\text { Giorgi }\end{array}$ & $\begin{array}{c}\text { Dialectic and dynamic } \\
\text { processes in constant } \\
\text { motion within and between } \\
\text { continually being in } \\
\text { affinity-being in loneliness, } \\
\text { being in power-being in } \\
\text { helplessness, and being in } \\
\text { continuity-being in } \\
\text { disruption. }\end{array}$ & $\begin{array}{l}\text { Response to } \\
\text { life close to } \\
\text { death } \\
\text { Beyond the } \\
\text { presence of } \\
\quad \text { death }\end{array}$ & K I \\
\hline $\begin{array}{c}\text { Tsigaroppoulos et } \\
\text { al } \\
(2009) \\
\text { Greece }\end{array}$ & $\begin{array}{l}\text { The aim was to survey } \\
\text { and record the various } \\
\text { problems faced by those } \\
\text { who care for cancer } \\
\text { patients at home. }\end{array}$ & $\begin{array}{l}\text { Quantitative } \\
76 \text { family caregivers } \\
\text { of people with } \\
\text { terminal cancer } \\
\text { The Problems and } \\
\text { Needs in Palliative } \\
\text { Care questionnaire- } \\
\text { caregiver form } \\
\text { (PNPC-c) was used } \\
\text { analyzed with } \\
\text { observational } \\
\text { statistical methods }\end{array}$ & $\begin{array}{l}\text { The most frequent problems } \\
\text { were: anxiety regarding the } \\
\text { patients future }(61.8 \%), \\
\text { troublesome symptoms such } \\
\text { as pain ( } 54 \% \text { \%), increased } \\
\text { economic burden - financial } \\
\text { difficulty }(51.3 \%), \\
\text { problems with patients } \\
\text { feeding }(50 \%) \text {, unhappiness } \\
\text { or depression }(48.7 \%), \\
\text { emotional upset }(47.4 \%), \\
\text { worsening of the patients } \\
\text { behavior and personality } \\
\text { ( } 38.2 \%) \text {, difficulty } \\
\text { establishing a positive } \\
\text { attitude regarding their } \\
\text { current status ( } 34.2 \%), \\
\text { transport to hospital }(32.9 \\
\%), \text { assistance from the } \\
\text { wider family circle }(25 \%) \text {. }\end{array}$ & $\begin{array}{l}\text { Response to } \\
\text { life close to } \\
\text { death } \\
\text { Beyond the } \\
\text { presence of } \\
\text { death }\end{array}$ & DS II \\
\hline
\end{tabular}


patient's body began to fail and that the former physical strength was now lacking affected the relatives both emotionally and realistically [21]. Observing how the disease or treatment changed the body also contributed to relatives' feelings of insufficiency [22]. Physical expressions in the patient were related to the relatives own physical reactions to the situation, such as muscle tension, headache, loss of appetite, and sleeplessness [24].

\section{Psychological Distress}

Death became real to relatives because they were constantly reminded of its presence. They lived with a continuous fear that the disease would deteriorate [19]. They suffered from psychosocial problems, such as depression and anxiety when the patient had "leave-takings" [22]. Relatives showed significantly higher levels of anxiety than patients [25], as well as higher levels of depression and overall psychological distress [23]. They had difficulties in expressing their emotions, such as depression and anxiety [24]. Feelings of insufficiency, powerlessness and helplessness were also experienced as the relatives felt that there was nothing else they could contribute with [21, 22]. Other experienced that they had come to terms with life, mortality and death. All this aroused feelings of awareness and reconciliation of life situation as well as overwhelming feelings of their failings and losses [26].

\section{Loneliness and Insecurity}

When patients suffering from dementia no longer could communicate, relatives experienced feelings of loneliness because they had no one to talk to [27], and consequently communication regarding life and death sometimes became difficult [26]. Relatives felt lonely when they had to take responsibility for all practical matters and they had feelings of isolation. It was not uncommon with experiences of existential loneliness in certain changes and circumstances during the disease trajectory [22]. Sometimes the situation was easier to endure when they were able to share their thoughts and feelings with the patient, which generated strength [26]. Other times the relative and the patient felt that they could not protect each other from suffering. The relatives were hovering between having experienced difficulties in the past and a readiness to manage the current life situation, as well as a need for the ability to use the necessary strengths and flexibility in daily life, learning to adapt to the situation in general. Sometimes they felt helpless, not having enough resources to manage the situation and found it difficult to know how to act in certain situations. Their trust in relations with healthcare staff was limited, the care provided was not helpful, and there was an unbalance between demands and expectations [26]. Feelings of anger directed towards the disease and healthcare staff were imminent [22].

Although relatives feared the occurrence of sudden adverse events, they strived to retain a positive attitude in their current situation [24].

\section{Responsibility and Guilt}

Reminded of the impending death relatives felt obligated to be faithful to their relation with the dying person, and that now was the time for them to repay all that they had previously received. Relatives were committed and involved in the care of the patient and did what they had to do without hesitation [20, 27]. Grown-up children to patients with severe or late stage dementia often felt like they had become a parent to their parent [27]. Other relatives of patients with

Table 2. Overview of the Overarching Theme, Categories, Subcategories and Papers Related to Each Sub-Category

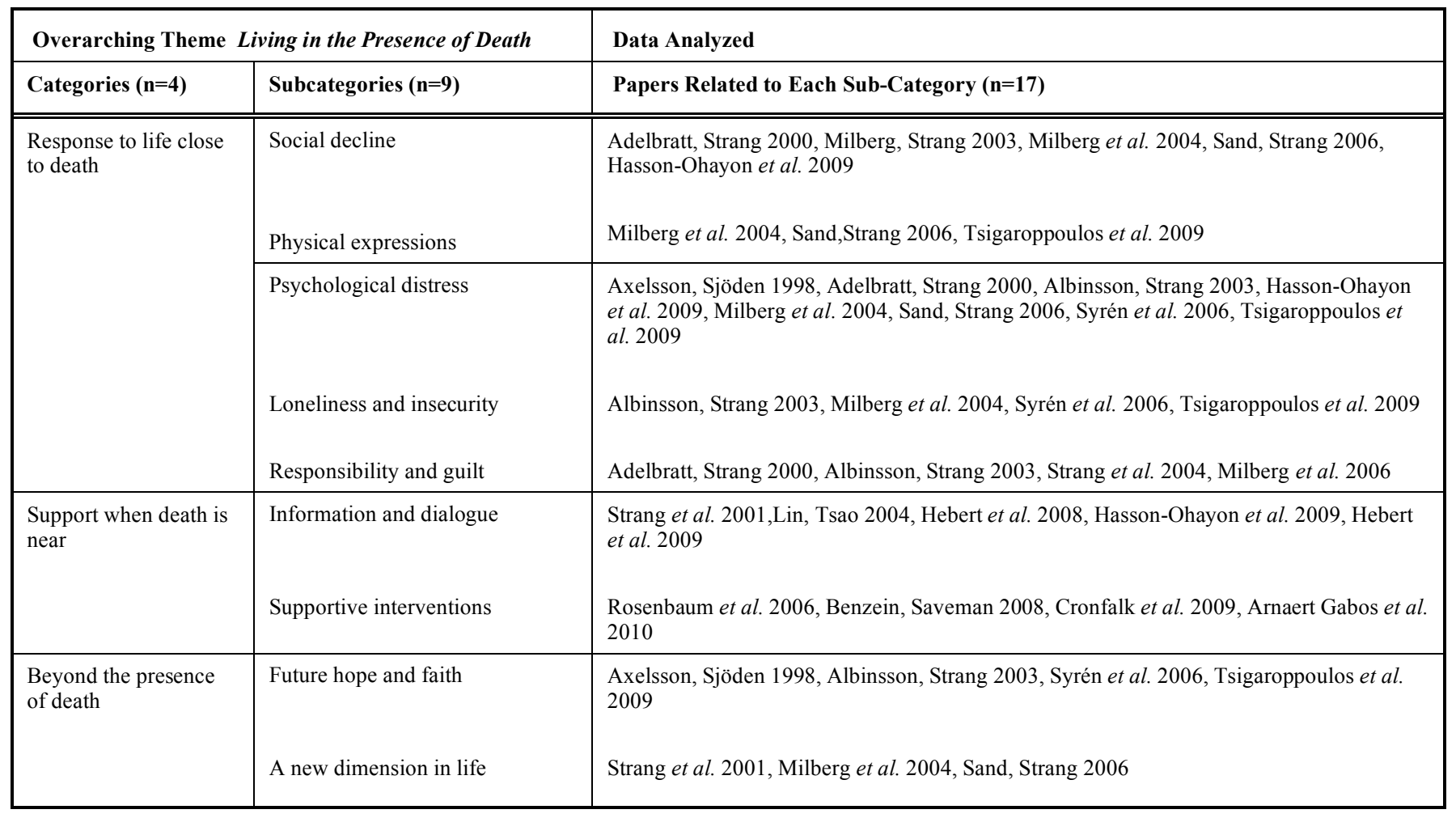


cancer could feel that they were responsible for alleviating suffering and initiating healthcare staff to act [21]. They felt a responsibility to protect and distract the patient from negative feelings, but they sometimes experienced lack of resources to relieve suffering. The relatives could also feel "survivors' guilt" about the disease and the situation to the dying person [19] and they felt guilty for not being able to do enough [22]. Other relatives found it difficult to express their emotions, for example sadness, but had no difficulty in expressing feelings of guilt [24].

\section{SUPPORT WHEN DEATH IS NEAR}

\section{Information and Dialogue}

The relatives wished for support from healthcare professionals in the form of a dialogue regarding chaos or information [28]. They expressed needs for medical, practical, psychosocial or religious/spiritual information when preparing for the death of the patient [29]. Relatives wanted healthcare staff to be present and needed confirmation from staff, i.e. they needed to be seen and acknowledged. Hindrance for providing support was staff's lack of a holistic view, fear and lack of time [30]. Relatives want to discuss issues of a religious/spiritual nature with healthcare professionals such as for example the meaning of illness, or "Who can I speak to about religious/spiritual concerns?" or "Why is this happening?" and "Will my loved one go to heaven?" [31]. Spouses of patients with breast cancer reported that social support from patients, family and friends, as well as religious or belief-based support were extremely important and could quite well have a protective role concerning psychological distress [23].

\section{Supportive Interventions}

Four papers were found which described interventions aimed at helping relatives existentially. Two of them concerned conversations, which were assumed as being helpful. The first paper was a nursing intervention consisting of three health-promoting conversations with dying cancer patients and their spouses in palliative home care. The conversations had a salotugenic approach involving the couple's recourses within and outside family as well as on health, hope and suffering encouraging them to reflect on their life situations. Talking about existential matters such as hope and suffering had a healing effect on participants. The couples experienced that they could unburden themselves and that they found new strategies for coping in daily life [32].

The second paper concerned life tape interviews with cancer patients and their relatives. The intervention consisted of 1-2 hour videotaped interviews in their home and an indepth life story including family history, significant life events and personal philosophy. The patients had the chance to reflect on their lives and face issues of mortality in the presence of relatives. Patients and relatives shared the experience, which provided the patient with a feeling of not being forgotten after death. This provided the patient with a sense of symbolic immortality and the patient served as a role model to others in the family of how to face dying and death. It helped relatives to respond to their sense of helplessness and loss when a loved one is facing death. This may contribute to how they manage to handle the existential anxiety about their own mortality [33].

The third intervention concerned a nonresidential 2.5 days retreat weekend for cancer patients' relatives. Various sessions were held during the retreat in which the participants shared stories with each other, the medical system was discussed, as well as the role of nutrition and complementary therapy. Sessions were also held about stress and relaxation response, and spirituality in cancer care as well as yoga, and group therapy. The relatives experienced emotional and spiritual healing that stemmed from a feeling of community with the other participants [34].

The fourth paper targeted relatives' well-being through soft tissue massage, and one of the outcomes was existential well-being. Soft tissue massage, hand or foot, was given to relatives of patients in palliative care in their homes for 25 minutes once a day during a period of two weeks. Relatives perceived that they felt an inner power, strength and existential well-being in everyday life after the massage, despite worries, tiredness and their stressful situation. This reflects the psychological, physical and existential needs of relatives when caring for a severely ill or dying family member [35].

\section{BEYOND THE PRESENCE OF DEATH}

\section{Future Hope and Faith}

Hope, purpose in life and meaningfulness were also present in the situation in that the relatives tried to find the meaning of illness $[25,27]$. The current meaning concerned knowledge and daily routines, and good memories could constitute the meaning in the past. The meaning in the future concerned passing on skills and interest of the patient to the next generation [27]. Experiencing hope was also an issue of importance to the feeling of future meaningfulness, for example hope of patients' improved well-being, which contributed to having something to look forward to [20]. Contacts with dead relatives and memories of them inspired confidence in eternal life, and spiritual power or a Christian faith was a source of hope. When awareness of mortality became obvious, the future became limited and short term goals were made only for the immediate future. It was difficult to find peace, and death was considered as disgusting [26]. Some relatives believed in God and their faith had not been affected due to the disease. Although church attendance was rare, a significant part of the relatives expressed that their faith had increased during illness [24]. In a study from Taiwan [36], it was found that relatives ranked spiritual issues as least important when caring for patients with cancer at the end of life.

\section{A New Dimension in Life}

Although living in the presence of death, relatives could sense a new dimension in life [28]. They perceived the patients' suffering, fading away and felt insufficient. Powerlessness and helplessness contributed to a deeper meaning, including existential and social aspects, such as feelings of guilt, anger and loneliness [22]. Relatives stuck to frames of reference from a healthy life for a longer period of the course of the illness. Step by step the former united lives separated and the patients started to conclude their lives 
while the relatives began psychological preparations for a changed but ongoing existence [21].

\section{DISCUSSION}

Although there is an increased attention in research about existential needs significant for patients with cancer, our review demonstrated that the knowledge about existential concerns actualized among relatives facing the death of a close family member are limited. This could be due to that existential needs in general are ignored in palliative care because of the uncertainty over definition, lack of theoretical understanding, few documented interventions, and the lack of proper training and education for palliative care providers [37].

Our review showed that a majority of papers are qualitative, have small samples and are from Sweden. Only a few individual or group interventions were found with the specific focus on how relatives' existential concerns were met. In another review it was described that a majority of family caregiver interventions are aimed to reduce stress levels, provide information and social support. A minority is designed particularly for family caregivers, and there is little evidence on the usefulness of these interventions in palliative care [38].

The lives of relatives living close to a severely ill person are influenced in many ways by the impending death. The awareness of living in the presence of death, while facing the death of a close family member i.e. mortality awareness, was a negative experience triggered by responses to life close to death. As for example social decline, physical expression manifested in different responses such as psychological distress, loneliness and insecurity, responsibility and guilt. In such a demanding situation relatives need professional and social support when perceiving a life beyond the presence of death. There are a variety of theories describing attitudes to death ranging from the strictly negative, which is rejecting death, towards attitudes of acceptance [39]. There is a pattern in our study that the relatives moved from the torment of watching their loved one fade away, constantly being reminded of death and responding to life close to death, through the illness trajectory towards a more "accepting" position.

Living in the presence of death was the overarching theme in our study concerning relatives who were constantly reminded of death that threatened their everyday life and normalcy. How they responded to this may be an expression of existential distress. Existential threats to normalcy may lead to fears of death which in itself may be embedded in anxiety for death. Fear has different meanings, for example the fear of being separated by death from your loved ones, or the finality of death (there is no more tomorrow) [39]. Existential distress may be an expression of death anxiety and the price one has to pay for living a genuine life [40] that is confronting ones fears as death, anxiety and uncertainty [41]. We found that relative's death anxiety increased which may be manifested in existential loneliness i.e. despite being surrounded by friends; one is quite alone in the situation. Sand expresses this phenomenon as "experiences of being alone in a world of one's own" [21].

Physical expressions in the patient were related to relatives own physical reactions to the situation, such as muscle tension, headache, loss of appetite, and sleeplessness. This is congruent with Merleau-Ponty who stated that people experience the world through their bodies can be seen as an object consisting of organs, bones, and flesh or a body as a subject, i.e. meaning is experienced from inside [42]. In a previous study [43] it was shown that a distressed body signals a message to the patient that death is approaching, and in the present study, we found that the same message is also conveyed to the relatives. Physical messages help the patients to prepare themselves for death, which is sometimes what patients want $[44,45]$. Relatives own physical reactions may help them to prepare that death are imminent. Environmental messages in for example a hospital may remind the relatives of impending death, and hinder the feeling "at-home" [46]. The difference between the physical and the environmental reminders of death is that the physical reminders are inevitable. The deterioration of the body and the progress of the disease could be constrained but not totally stopped, but the hospital environment could be changed to become more welcoming and home-like.

Need of existential support was described in some papers in this review as well as opinions about how this could or ought to be provided by healthcare professionals. This is an implication for healthcare professionals to acknowledge and support relatives having existential needs, emphasize their vulnerable situation and existential distress. Nurses are of importance in providing spiritual support to relatives but are sometimes inadequately equipped to provide such support [47]. Spirituality in nursing is described as a multidimensional concept without any consensus about how it may be defined. Many nursing authors though include elements such as "transcendence, unfolding mystery, connectedness, meaning and purpose in life, higher power, and relationships", and spirituality may or may not be related to religion [48]. In complex situations nurses may consider being guided by openheartedness, which is being grounded in the existential dimensions of being human. This is important, especially as care today is exceptionally technical and instrumental. It can be integrated in the interaction with a dying patient and the family by being close and not abandoning them, being open to their vulnerability without treating them as objects, using all technical recourses, specialized training and lived experiences. Nursing openheartedness is responsive to patients and families' different needs from the very practical to the most existential [49].

Relatives want support from healthcare professionals in terms of information and dialogue. They need to be provided with adequate information about the disease as well as having someone to confide in and continually communicate with healthcare professionals. This may prevent and/or shed a light on possible conflict of interests, which was also found in another study of relatives of patients with amyotrophic lateral sclerosis (ALS) [50]. Staffs themselves perceive that they have a responsibility to provide existential support to cancer patients at the end of life. But there is a gap between the patient's wish to discuss existential issues as healthcare staff lack strategies to meet them. This gap could be bridged by healthcare staff inviting them to a dialogue on existential issues [51]. There is a need to provide support groups, focusing on relatives' existential distress and death anxiety, when caring for a seriously ill family member. Support 
groups are highly important to cancer patients and their families [52]. To participate would probably increase relatives' feeling of security when living in the presence of death, and give them a sense of security in relation to the ill family member, the illness and nursing staff [53].

A new dimension was experienced by relatives, despite the situation being distressful. They experienced a glimpse of a new life following the period of illness. This indication was conveyed by relatives having positive feelings about future hope and faith. Hope has previously been found to be an essential resource in the lives of people with cancer helping them to cope during times of suffering and uncertainty. For relatives it was a gradual process of regaining strength and moving on $[54,55]$. A new dimension in life could be the result of relative's letting go of the ill person and may be a crucial turning point. "Letting go before death" attributes recognition of the fact that the loved one is dying and will die, acknowledging the impending physical and emotional loss that will occur at the time of death, and allowing the progression of inevitable death to occur by choosing not to prolong or impede this natural process [56]. After the death of loved a one, many relatives are in need of bereavement follow-up. They need to talk about the past, the present and the future, they need comfort in a situation of loneliness and there is a need to put words to emotions [57].

\section{CONCLUSION}

In this paper we present the fact that research concerning relatives' existential concerns when caring for a seriously ill family member is limited. There is a need for large-scale studies with accurate methodology both qualitative and quantitative, mainly randomized controlled studies when investigating relatives' existential concerns. Relatives living in the presence of death and being in a transitional phase need continual support from professionals, for example through dialogue. Relatives appeal for discussions relating to issues of an existential nature, such as "Why is this happening?" and stress the need for knowledge as well as strategies among healthcare professionals. Therefore educational interventions among professionals in different healthcare settings are needed, to extend knowledge about existential concerns among relatives. It is important that healthcare professionals understand the struggle relatives experience when living in the presence of death, and that they infuse future hope and faith through continuing dialogues, which may support the relatives in the transition into a new dimension in life.

\section{ACKNOWLEDGEMENT}

To The Sahlgrenska Academy, University of Gothenburg, Sweden for funding this study and to Dorothy Björklund for linguistic revision.

\section{CONFLICT OF INTEREST}

There is no conflict of interest concerning this manuscript.

\section{REFERENCES}

[1] Doyle-Browne M. The transitional phase: The closing journey for patients and family caregivers. Am J Hosp Palliat Care 2000; 17: 354-7.
[2] Steinhauser KE, Christakis NA, Clipp EC, et al. Preparing for the end of life: preferences of patients, families, physicians, and other care providers. J Pain Symptom Manage 2001; 22: (3) 727-37.

[3] Saunders C. Spiritual Pain. J Palliat Care 1988; 4: 29-32.

[4] World Health Organization. National Cancer Control Programmes: Policies and Managerial Guidelines. 2nd ed. Geneva. 2002. Available from http://www.who.int/cancer/publications/en/\#guide lines. [Accessed: 17 September 2010].

[5] Henoch I, Danielson E. Existential concerns among patients with cancer and interventions to meet them: an integrative literature review. Psychooncology 2009; 18:225-36.

[6] Yalom I. Existential Psychohterapy. Basic Books Inc. Publisher, New York 1980.

[7] Ferell BR (1996) The quality of lives: 1525 voices of cancer. Oncol Nurs Forum 23: 909-16.

[8] Chochinov HM. Dying, dignity, and new horizons in palliative endof-life care. CA Cancer J Clin 2006; 56: 84-103.

[9] Breitbart W, Gibson, C, Poppito SR, Berg A. Psychotherapeutic interventions at the end of life: a focus on meaning and spirituality. Can J Psychiatry 2004; 49: 366-72.

[10] Strang S. Spiritual/existential issues in palliative care. Dissertation, Göteborgs University 2002.

[11] Morita T, Kawa M, Honke Y, et al. Uchitomi Y. Existential concerns of terminally ill cancer patients receiving specialized palliative care in Japan. Support Care Cancer 2004; 12: 137-40.

[12] Murata H, Morita T, Japanese task force. Conceptualization of psycho- existential suffering by the Japanese task force: the first step of a nationwide project. Palliat Support Care 2006; 4: 279-85.

[13] Morita T, Tsunoda J, Inoue S, Chihara S. An exploratory factor analysis of existential suffering in Japanese terminally ill cancer patients. Psychooncology 2000; 9:164-68.

[14] Andershed B. Relatives in end-of-life care - part 1: a systematic review of the literature the first five years, January 1999 - February 2004. J Clin Nurs 2006; 15: 1158-69.

[15] Hudson P, Aranda S, McMurray N. Intervention development for enhanced lay palliative caregiver support - the use of focus groups. Eur J Cancer Care 2002; 11: 262-70.

[16] Berg A, Denker K, Skärsäter I. Evidence based nursing when treating persons with depression. [Swedish]. SBU-rapport 1999. Evidensbaserad omvårdnad vid depressionssjukdomar. SBU/SSF nr 3. Available from: http://www.sbu.se/sv/Publicerat/Vit/Evidensbas erad-omvardnad-vid-behandling-av-personer-med-depressionssjukd omar [Accessed 17 September 2010].

[17] Goodman C. Literature search and evidence interpretation for assessing health care practices. [Swedish]. SBU-rapport 1993. Statens beredning för utvärdering av medicinsk metodik.

[18] Hartman J. Scientific thinking. From theory of knowledge to theory of methods. [Swedish]. Vetenskapligt tänkande. Från kunskapsteori till metodteori. Studentlitteratur Lund 1998.

[19] Adelbratt S, Strang P. Death anxiety in brain tumour patients and their spouses. Palliat Med 2000; 14: 499-507.

[20] Milberg A, Strang P. Meaningfulness in palliative home care: an interview study of dying cancer patients' next of kin. Palliat Support Care 2003; 1:171-80.

[21] Sand L, Strang P. Existential loneliness in a palliative home care setting. J Palliat Med 2006; 9:1376-87

[22] Milberg A, Strang P, Jakobsson M. Next of kin's experience of powerlessness and helplessness in palliative home care. Support Care Cancer 2004; 12:120-28.

[23] Hasson-Ohayon I, Goldzweig G, Braun M, Galinsky D. Women with advanced breast cancer and their spouses: diversity of support and psychological distress. Psychooncology 2009; 19: 1195-204.

[24] Tsigaroppoulos T, Mazaris E, Chatzidarellis E, Skolarikos A, Varkarakis I, Deliveliotis C. Problems faced by relatives caring for cancer patients at home. Int J Nurs Pract 2009; 15: 1-6.

[25] Axelsson B, Sjöde'n PO. Quality of life of cancer patients and their spouses in palliative home care. Palliat Med 1998; 12: 29-39.

[26] Syrén S, Saveman B, Benzein E, et al. Being a family in the midst of living and dying. J Palliat Care 2006; 22: 26-32.

[27] Albinsson L, Strang P. Existential concerns of families of late-stage dementia patients: questions of freedom, choices, isolation, death, and meaning. J Palliat Med 2003; 6: 225-35.

[28] Strang S, Strang P. Spiritual thoughts, coping and sense of coherence in brain tumour patients and their spouses. Palliat Med 2001; 15: 127-34. 
[29] Hebert RS, Schulz R, Copeland VC, Arnold RM. Preparing family caregivers for death and bereavement. Insights from caregivers of terminally ill patients. J Pain Symptom Manage 2009; 37: 3-12.

[30] Strang S, Strang P, Ternestedt BM. Existential support in brain tumour patients and their spouses. Support Care Cancer 2001; 9: 625-33.

[31] Hebert RS, Schulz R, Copeland VC Arnold RM. What questions do family caregivers want to discuss with health care providers in order to prepare for the death of a loved one? An ethnographic study of caregivers of patients at the end of life. J Palliat Med 2008; 11: 476-83.

[32] Benzein E, Saveman B. Health-promoting conversations about hope and suffering with couples in palliative care. Int J Palliat Nurs 2008; 14: 439-45.

[33] Rosenbaum E, Garlan RW, Hirschberger N, Siegel AL, Butler LA, Spiegel D. The Life Tape Project: Increasing family social support and symbolic immortality with a brief existential intervention for cancer patients and their families. J Death and Dying 2006; 53 : 321-39.

[34] Arnaert A, Gabos T, Ballenas V, Rutledge RD. Contributions of a retreat weekend to the healing and coping of cancer patients' relatives. Qual Health Res 2010; 20: 197-208.

[35] Cronfalk, B, Strang P, Ternestedt BM. Inner power, physical strength and existential well-being in daily life: relatives' experiences of receiving soft tissue massage in palliative home care. J Clin Nurs 2009; 18: 2225-33.

[36] Lin WC, Tsao CJ. Information needs of family caregivers of terminal cancer patients in Taiwan. Am J Hosp Palliat Care 2004; 21: 438-44.

[37] Boston P, Bruce A, Schreiber R. Existential suffering int the palliative care setting: An integrated literature review. J Pain Symptom Manage 2011; 41: 604-18.

[38] Harding R, Higginsson IJ. What is the best way to help caregivers in cancer and palliative care? A systematic literature review of interventions and their effectiveness. Palliat Med 2003; 17: 63-74.

[39] Tomer A, Grafton GT, Wong PTP, eds. Existential and Spiritual issues in death attitudes, Taylor and Francis, New York 2008.

[40] Neimeyer RA, Eds. Death anxiety handbook, Taylor and Francis, Washington DC 1994

[41] Greenberg J, Koole SL, Pyszczynski T (ed) Handbook of experimental existential psychology, The Guilford Press, New York 2004.
[42] Merleau-Ponty M. Phenomenology of Perception. Routledge, London 2002.

[43] Melin-Johansson C, Axelsson B, Danielson E. The meaning of quality of life: narrations by patients with incurable cancer in palliative home care. Palliat Support Care 2008; 6: 231-38.

[44] Nelson ML, Schrader SL, Eidsness LM. South Dakota's dying to know: personal experiences with end-of-life care. J Palliat Med 2009; 12: 905-13.

[45] Prince PM. When hospice is the best option: an opportunity to redefine goals. Oncology (Williston Park) 2009; 23: 13-7.

[46] Rasmussen BH, Edvardsson D. The influence of environment in palliative care: supporting or hindering experiences of 'athomeness'. Contemp Nurse 2007; 27: 119-31.

[47] Kuuppelomäki M. Spiritual support for families of patients with cancer: a pilot study of nursing staff assessments. Cancer Nurs 2002; 25: 209-18.

[48] Tanyi R. Towards a clarification of the meaning of spirituality. J Adv Nurs 2002; 39:500-09.

[49] Galvin KT, Todres L. Embodying nursing openheartedness: an existential perspective. J Holist Nurs 2009; 27: 141-9.

[50] Bolmsjö I, Hermerén G. Conflicts of interest: experiences of close relatives of patients suffering from amyotrophic lateral sclerosis. Nurs Ethics 2003; 10: 186-98.

[51] Browall M, Melin-Johansson C, Strang S, Danielson E, Henoch I. Health care staff's opinions about existential issues among patients with cancer. Palliat Support Care 2010; 8: 59-68.

[52] Weis J. Support groups for cancer patients. Support Care Cancer 2003; 11: 763-8.

[53] Henriksson A, Andershed B. A support group programme for relatives during the late palliative phase. Int J Palliat Nurs 2007; 13: 175-83.

[54] McClement SE, Chochinov HM. Hope in advanced cancer patients. Eur J Cancer 2008; 44: 69-117.

[55] Holtslander LF, Duggleby WD. The hope experience of older bereaved women who cared for a spouse with terminal cancer. Qual Health Res 2009; 19: 388-400.

[56] Lowey SE. Letting go before a death: a concept analysis. J Adv Nurs 2008; 63: 208-15.

[57] Milberg A, Olsson EC, Jakobsson M, Olsson M, Friedrichsen M. Family members' perceived needs for bereavement follow-up. J Pain Symptom Manage 2008; 35: 58-69.

(C) Melin-Johansson et al.; Licensee Bentham Open.

This is an open access article licensed under the terms of the Creative Commons Attribution Non-Commercial License (http://creativecommons.org/licenses/ by-nc/3.0/) which permits unrestricted, non-commercial use, distribution and reproduction in any medium, provided the work is properly cited. 